\title{
ホームユースのシクラメン鉢物の生育が消費者の感情に及ぼす影響
}

\author{
朴＼cjkstart昭英 $*$ ・山根健治・藤重宣昭・八巻良和 \\ 宇都宮大学農学部 321-8505 宇都宮市峰町
}

\section{Effects of Growth and Development of Potted Cyclamen as a Home-Use Flower on Consumers' Emotions}

\author{
So-young Park*, Kenji Yamane, Nobuaki Fujishige and Yoshikazu Yamaki \\ Faculty of Agriculture, Utsunomiya University, Utsunomiya 321-8505
}

\begin{abstract}
Potted cyclamens, a popular indoor plant during the winter season, were used in this study. Differences in plant growth status depending on the individuals who cared for them and the responses of human emotion to the plant were examined. Forty-six women (mean age $=46.1$ ) living in Tochigi prefecture were asked to care for potted cyclamens in their homes for three months. Growth and quality varied greatly with the subjects. The plants were classified into five groups depending on their status after three months. Self-evaluation $(r=0.7, p<0.001)$, satisfaction $(r=0.61, p<0.001)$ and pleasure $(r=0.38, p<0.012)$ of the subjects correlated with the growth and quality of the plant in their care. On POMS, the scores for Tension-Anxiety (T-A), Depression-Dejection (D), Anger-Hostility (A-H), and Confusion (C) dropped significantly due to the intervention of the plant into the household, but these scores were slightly increased on the final test after three months. The categories of D and A-H were especially decreased in the group with the best plant quality. On the egograms in the group with the best quality plants, the scores for Nurturing Parent (NP), Adult (A) and Free Child (FC) were slightly increased, while that of Adapted Child (AC) was decreased. As for the semantic differential technique, factor analysis was performed based on twenty-six semantic differential (SD) scales on sensory evaluation. Among the three extracted factors, 'comfortable' and 'gorgeous' increased but 'simple and clean' decreased with the introduction of the potted cyclamen. The results indicated not only positive effects of potted plants on consumers' emotions, shown by scores for as $\mathrm{D}, \mathrm{A}-\mathrm{H}$ and 'comfortable', but also a certain level of relationship between plant growth and the satisfaction and pleasure of the owner.
\end{abstract}

Key Words : egogram, POMS, postharvest quality

キーワード：エゴグラム，気分プロフィール検査，出荷後の品質

\section{緒言}

近年，植物による人間の反応や心身の変化に関する様々 な研究がなされている，たとえば，植物のスライドやビデ オを見せることによる精神的ストレスからの回復 (Parsons ら, 1998; Son, 2004), 学校やオフィスなどへの植物の導入 による健康や集中力などの改善（Fjeld, 2000; 今西ら，2002; Lohr ら，1996）, 実験室においてプランターの植物を育てた とき（遠藤ら，2001）や，鉢苗の植え替え作業を行ったと き（山根ら，2002）の心拍変動, 脳波拈よび感情面への短 期的な影響についてのケーススタディ，高齢者施設に打け る園芸活動と高歯者の身体および精神的な生活の質（QOL） についての介入型研究（杉原ら，2005; 安川ら，2000）な どがあげられる。しかし，植物の状態による人間の長期間 の反応を調査する研究, さらに自宅で被験者自ら育てなが

2007 年 5 月 16 日 受付. 2007 年 10 月 4 日 受理.

本報告の一部は園芸学会平成 18 年度秋季大会で発表した.

* Corresponding author. E-mail: bsoyoung78@yahoo.co.jp
ら行う実験はほとんどなかった。

室内に颃ける植物栽培の心理的な影響を調査するため, 花と葉のボリュームがあり長期にわたって利用できるシク ラメンの鉢物に着目した. シクラメンは冬季の代表的な鉢 物であり，平成 18 年の卸売り数は 1672 万鉢で鉢物の種目 別では最も取扱数量が多い（農林水産省, 2007). しかし, 卸売り価格は低下する傾向にあり，生産性の向上とともに 消費者のもとでの品質保証も今後の消費拡大に重要である （福井，2006）。これまでシクラメンの収穫後の品質につい ての試験は， ほとんどが試験研究機関で行われてきた.

そこで，本研究では一般消費者がシクラメンを自宅で栽 培したときの，シクラメン鉢物の生育と品質の変化を調査 するとともに，その存在や生育状況が部屋の印象，人の気 分，自我状態などに及ぼす影響について検討した。

\section{材料および方法}

\section{1. 実験材料}

栃木県在住の一般女性 46 名（平均年齢 46.1 才， $25 \sim 75$ 
才）を被験者とした。栃木県内で生産された普通系シクラ メン (Cyclamen persicum Mill.) の代表品種 ‘バーバーク’ (赤) の 20 輪以上開花している株（5号鉢）を供試した. 被 験者 1 人につき 1 株とし, 鉢血と追肥用 IB 化成一袋も同時 に渡した。

\section{2. 実験方法}

2006 年 1 月 29 日から 5 月 9 日までの約 3 か月間, 各被験 者の自宅でシクラメンを育ててもらった. 本研究の目的は シクラメンの成長と人間の反応との関係を見ることだが, 目的を説明したときの侵襲を避けるために被験者にはシク ラメン品種の品質評価の名目で実験に参加してもらった.

シクラメンを導入前と導入 1,2 および 3 か月後に, 被験 者の室内の印象評価に関するアンケート, 気分プロフィー ル検査 (POMS, 金子書房) 扎よび東大式エゴグラム調査 （TEG，金子書房）を行った.

\section{3. 測定項目}

\section{1）シクラメンの生育状況の調査}

シクラメンの生育状況は 1 か月毎に被験者に写真を撮つ てもらい, 実験開始前と終了時に実験室において葉数, 花 数, 草丈, 株張りを測定した. 葉, 根および塊茎に分解し, 各部位の新鮮重および乾物重を測定した. 18 個の鉢にボタ ン式温度ロガー（Tomprobe, GSI クレオス社）をセットし，
被験者のもとでの管理温度を測定した。

\section{2）アンケート調査}

実験開始前に年齢, 植物を飾る程度, 子育て経験の有無, 植物栽培経験の有無, 栽培失敗経験の有無などを問い, 実験 参加後にはシクラメンの状態を見て自分の栽培出来栄えに 点数をつける自己評価, 満足度, 楽しさ, 感想などを聞いた。

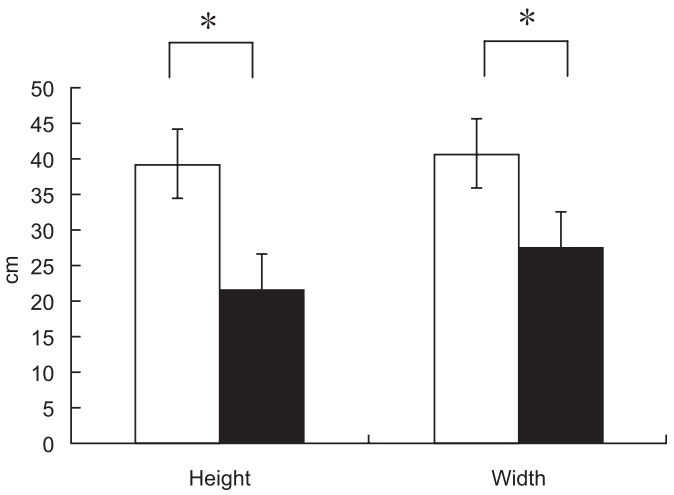

第 1 図 消費者のもとで3か月間栽培されたシクラメンの草丈 と株張りの変化

\section{$\square$ : 開始前 口: 3 か月後}

縦棒は標準誤差を示す $(n=46)$.

$* \mathrm{t}$ 検定により $5 \%$ 水準で有意差あり

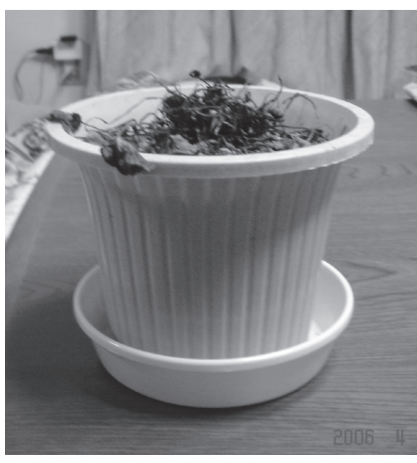

Gra d e 1

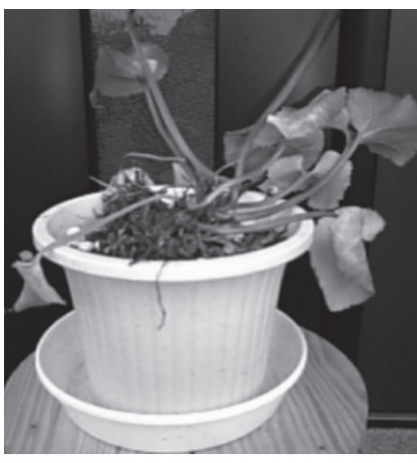

Gra d e 2

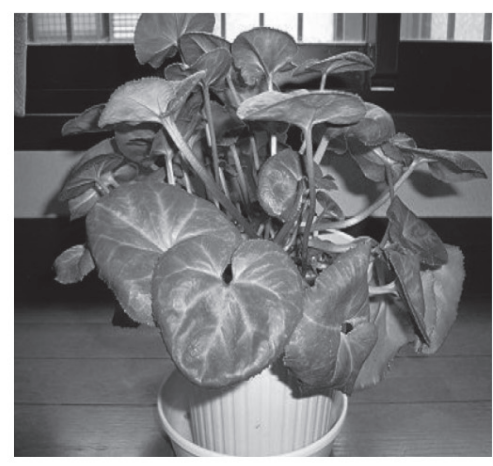

Gra d e 3

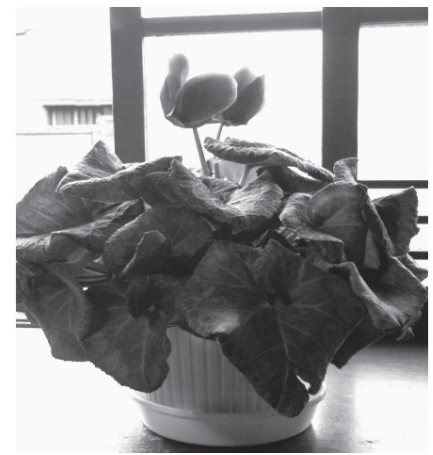

Gra d e 4

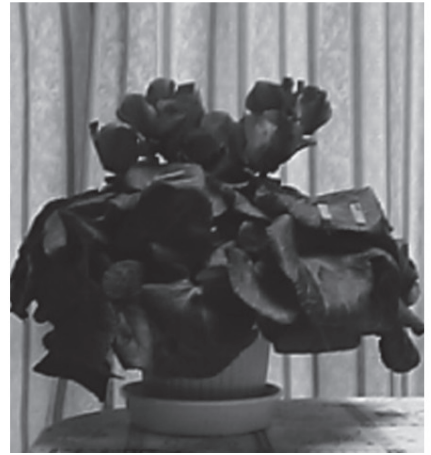

Gra d e 5

第 2 図消費者のもとで3か月間栽培されたシクラメンの生育状況別代表例 Grade 1 （生育不良）から Grade 5（健全）に分類 
シクラメンを置いた室内の印象に関しては，実験開始時 とその後 1 か月ごとに被験者の対象についての心理反応を 形容詞対の評価尺度に回答をもらう SD 法によるアンケー トを用いて調査した（仁科・中本，1998）。内容は，明るさ， 陽気さ，安らぎ，きれいさ，香りなど 26 項目であり，いず れも 7 段階評価からなる。

\section{3) POMS (Profile of Mood States)}

POMS は主観的側面の評価を目的とした気分プロフィー ル検査で緊張一不安（T-A），抑らつ一落ち込み（D)，怒り 一敵意 $(\mathrm{A}-\mathrm{H})$, 活気 $(\mathrm{V})$, 疲労 $(\mathrm{F})$, 混乱 $(\mathrm{C})$ の六つ の気分尺度を測定するものである（横山・荒記，1994）。

\section{4) TEG (Tokyo University Egogram)}

エゴグラムは Berne が創始した交流分析理論に基づき， 弟子の Dusay が考案したものである（東京大学医学部心療 内科 TEG 研究会, 1999). 人の自我状態を批判的親 (CP), 養育的親 $(\mathrm{NP})$, 大人 $(\mathrm{A})$, 自由な子供 $(\mathrm{FC})$, 適応した 子供（AC）の 5 項目で評価できる.

\section{4. 統計処理}

データはソフトウエア（JMP Ver. 5.0, SAS 社）を用いて, $\mathrm{t}$ 検定, Wilcoxon の符号付き順位検定, 分散分析拉よび Tukey の HSD 検定を適宜行った。印象評価アンケートの結果は 評価尺度間の相関係数を求め, Varimax 回転を用いて因子 分析し，因子スコアの変化を示した.

\section{結果}

シクラメンの生育状態は, 実験開始前の值に比べて, 草 丈は $39 \mathrm{~cm}$ から $21 \mathrm{~cm}$ に, 株張りは $40 \mathrm{~cm}$ から $27 \mathrm{~cm}$ に有 意に減少した (第 1 図). 平均的な 5 鉢を選しで調査した新 鮮重と乾物重は塊茎を除くいずれの部位に打いても減少し ており，特に花の重さが著しく減少した（データ省略）.

実験開始 3 か月後の植物の状態によって Grade 1 (生育不 良）から Grade 5 （健全）に分類した（第 2 図）。花も葉も 無しの Grade 1 が 9 ケース，花無しで葉が数枚ある Grade 2 が 5 ケース, 花無しで葉数が 100 枚以下の Grade 3 が 13 ケース, 花 3 輪以下と葉数 100 枚以上の Grade 4 が 8 ケー ス, 花 3 輪以上で観賞価値が最も高い Grade 5 が 11 ケース であった。

被験者がシクラメンを管理している部屋の温度の平均は $14.3^{\circ} \mathrm{C}$ であった。ボタン式温度ロガーを設置した 18 個は Grade 2 以外の Grade 1 から Grade 5 までそれぞれ 4 個から 5 個の分布であった。 そのらち植物の状態がもっとも悪い Grade 1 の被験者宅に扮いては平均 $13.8^{\circ} \mathrm{C}$ とやや低い傾向 であった．同一室内に抢ける実験期間中の最高温度と最低 温度の差の平均は $18.9^{\circ} \mathrm{C}$ であったが, Grade 1 では $20.4^{\circ} \mathrm{C}$ と最も大きかった。

被験者の自己評価の結果, Grade 1 の被験者の自己評価は 植物の状態が悪くなっていくとともに点数も有意に低く なった (第 3 図 a). 満足度の変化を植物の状態 Grade 別に 比較すると Grade 1 の被験者では徐々に低下するが, Grade
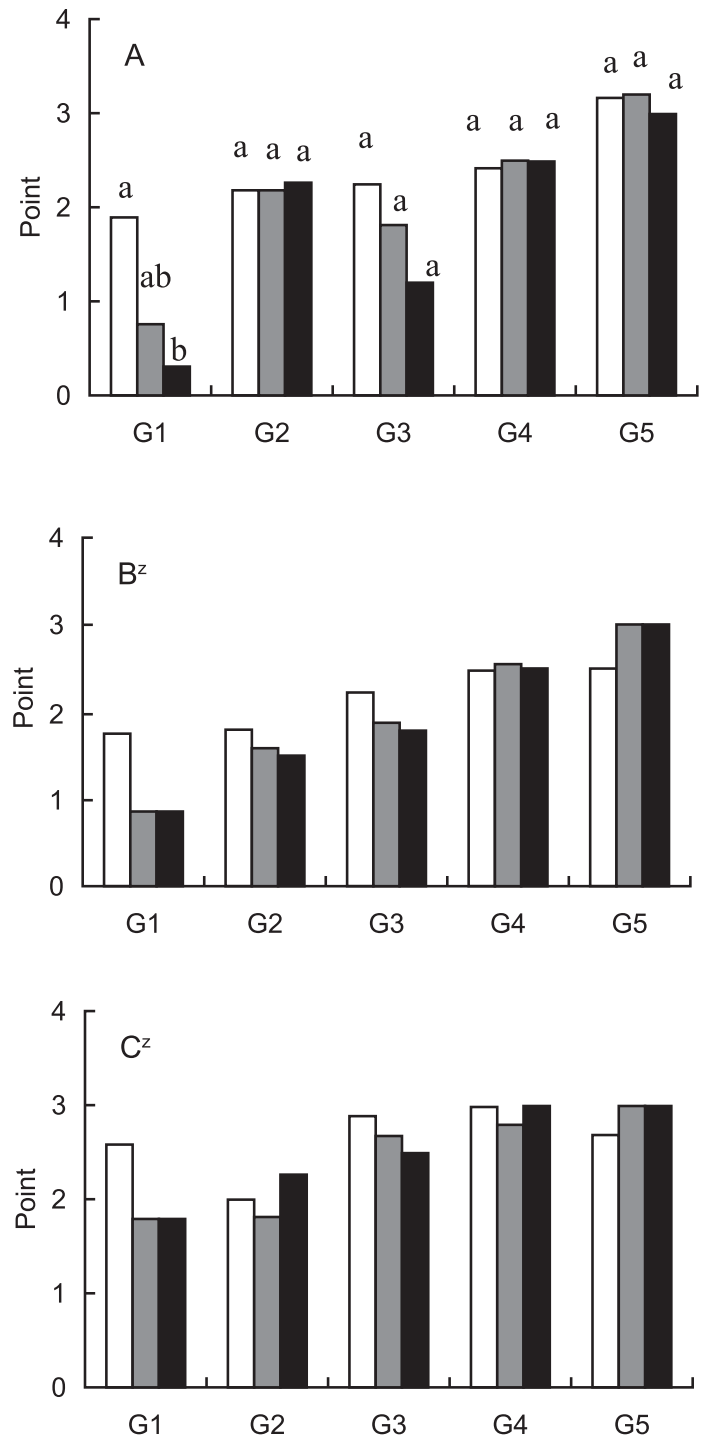

第 3 図 植物の生育状態別（第 2 図）の被験者に打ける自己評 価 $(\mathrm{A})$, 満足度（B）拈よび楽しさ（C）の変化 $\square: 1$ か月後 $\square: 2$ か月後 $\square: 3$ か月後 同一文字間には有意差なし（Tukey の HSD 検定） $\mathrm{z}$ 分散分析が有意ではないので多重検定省略

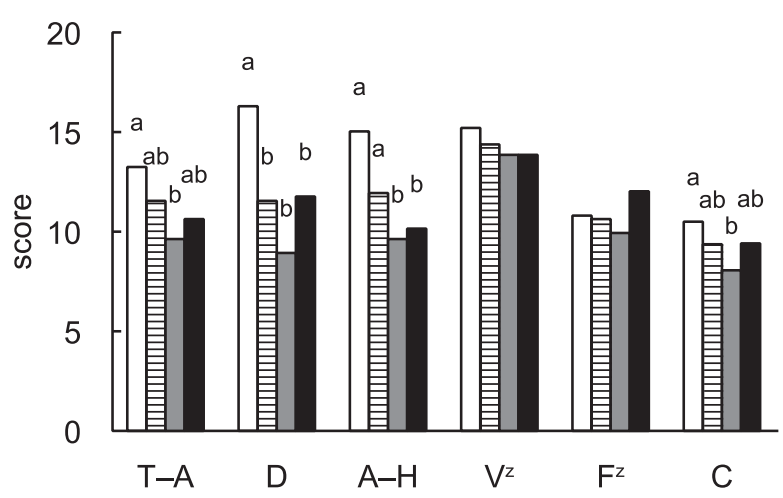

第 4 図 シクラメンの栽培 3 か月間に打ける POMS 得点の変 化 $(n=46)$

$\square$ :開始 目: 1 か月後 $\square: 2$ か月後 $\square: 3$ か月後 同一文字間には有意差なし（Tukey の HSD 検定）

$\mathrm{z}$ 分散分析が有意ではないので多重検定省略 

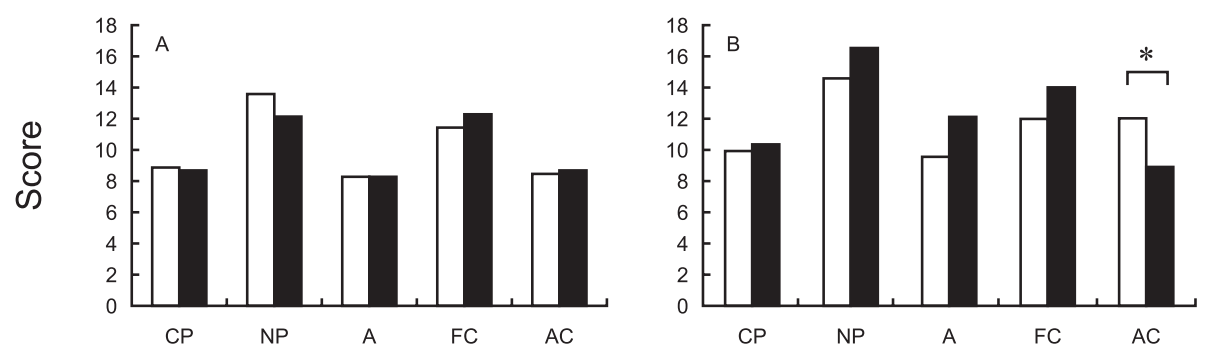

第 5 図 3 か月間の栽培前後におけるエゴグラムの比較
A : Grade1 $(n=9)$ B : Grade5 $(n=11)$
$\mathrm{CP}$ : 批判的親 $\mathrm{NP}$ : 養育的親 $\mathrm{A}$ : 大人
$\mathrm{FC}$ : 自由な子供 $\mathrm{AC}$ : 適応した子供
$\square:$ 開始前 $\square: 3$ 力月後

*Wilcoxon の符号付き順位検定により栽培前後に 5\%水準で有意差あり

5 の被験者の満足度は高く維持されていた（第 3 図 b). 楽 しさの変化も, Grade 1 と Grade 5 の被験者に颃いては，満 足度とほぼ同じ傾向がみられた（第 3 図 c).

気分を評価する POMS の測定において，植物の導入に よって T-A，D， A-H および C の平均得点の有意な低下が 認められた (第 4 図). 特に, 植物の状態によって被験者を 分けてみると, Grade 1 より Grade 5 の被験者の D およびA$\mathrm{H}$ の平均得点の低下が大きかった（データ省略）.

自我状態を評価するために用いたエゴグラムの全体平均 に拈いては変化がみられなかった（データ省略）。しかし， 植物の状態により分けたグループ別にみると, Grade 1 グ ループではほとんど変化が認められなかったが, Grade 5 グ ループでは ACが有意に低下し， NP，A および FCの平均 得点はやや上昇する傾向が久られた（第 5 図）.

印象評価アンケートの因子分析の結果，固有值 1 以上の 3 因子が抽出され，累積寄与率は合わせて $65 \%$ であった. 「かたい一やわらかい」，「安らぎのない一安らぎのある」， 「陰気な一陽気な」などで構成される第 1 の因子を「快適 さ」の因子とした。「複雑な一簡単な」，「けばけばしい一 あっさりした」，「ほこりっぽい一空気がきれい」などから なる第 2 因子を「簡素さ・清潔さ」に集約した。「地味な一 派手な」,「無機的な一有機的な」,「単調な一変化に富んだ」 などの第 3 因子を「華やかさ」と集約した。 これらの因子 得点はシクラメンを飾ることにより「快適さ」と「華やか さ」は高まり，「簡素さ・清潔さ」は低下する傾向が認めら れた（第 6 図）。

\section{考 察}

シクラメンの 3 か月後の開花状況は被験者によって様々 であり，実験開始時には同じ品質の鉢物でも管理方法に よって品質が大きく異なってくることが確認された（第 2 図)。特に平均温度が低く，温度較差が大きい場所で管理さ れた個体の品質が低下していた. 一方, 植物の生育状態 (第 2 図）と人の自己評価 $(r=0.7, p<0.001)$ や満足感 $(r=0.61$, $\mathrm{p}<0.001)$, 楽しさ $(\mathrm{r}=0.38, \mathrm{p}<0.012)$ （第 3 図）との間に
それぞれ相関が認められたことから，生育状態が消費者の 心理に影響することが示唆された。

短期的な園芸作業によって POMS の得点が低下，すなわ ち気分が改善されることは報告されている（遠藤ら，2001； 深澤，2005; 林ら，1999; 山根ら，2002）。本実験では，被 験者の気分を評価する POMS の測定では植物の導入によっ て，T-A，D， A-H 扣よび C の平均得点の有意な低下が認め られた (第 4 図)。このことは, シクラメンが緊張, 不安, 抑らつ，怒りおよび頭の混乱などを緩和したことを示唆し ている，特に，植物の生育を Grade 1 から 5 に分けてみる と Grade 1 のグループより Grade 5 のグループでの D や A$\mathrm{H}$ の平均得点の低下が大きかったことから，生育状況の良 かった被験者でより大きな抑らつや怒りの緩和作用があっ たと考えられる.

自我状態を評価するエゴグラムでは，3 か月間の園芸療 法後に高齢者に拈いて NP 拈よび FC の上昇と $\mathrm{AC}$ の低下が 報告されている（安川ら，2000）。本研究においては，生育 の良かった Grade 5 グループに打いて AC は低下し, NP, A 扣よび FC は上昇傾向にあった（第 5 図）。しかし，被験者 全体としては自我の変化は認められなかったことから，鉢 物が自我状態に及ぼす影響についてはさらに長期にわたる 調査が必要と考えられる.

観葉植物の効果に関して，今西ら（2002）はオフィスへ 観葉植物を導入すると快適さや雾囲気の好感度が増すこと や特に花物では「はっきりした」「明るい感じ」「豪華な」 などの評価が高いことを報告している，本実験では，印象 評価アンケートの「快適性」と「華やかさ」はシクラメン の導入によって高まった（第 6 図）。

今回使用したシクラメンが赤色のため, 暖かさ，陽気さ， 派手さ，力強さなどの要素を高めた可能性もある. といら のは, 赤色は暖色に属し, 暖かい, 積極的, 怒り, 歓喜, 活動的，興奮などの感情を与えるとされている（日本色彩 学会, 1998）し，ペチュニアの花色と印象との研究に拈い て，赤は「高揚感」，「快活さ」をもたらすとともに，「安定 感」を低下させた（金・藤井，1995）からである。ただし 


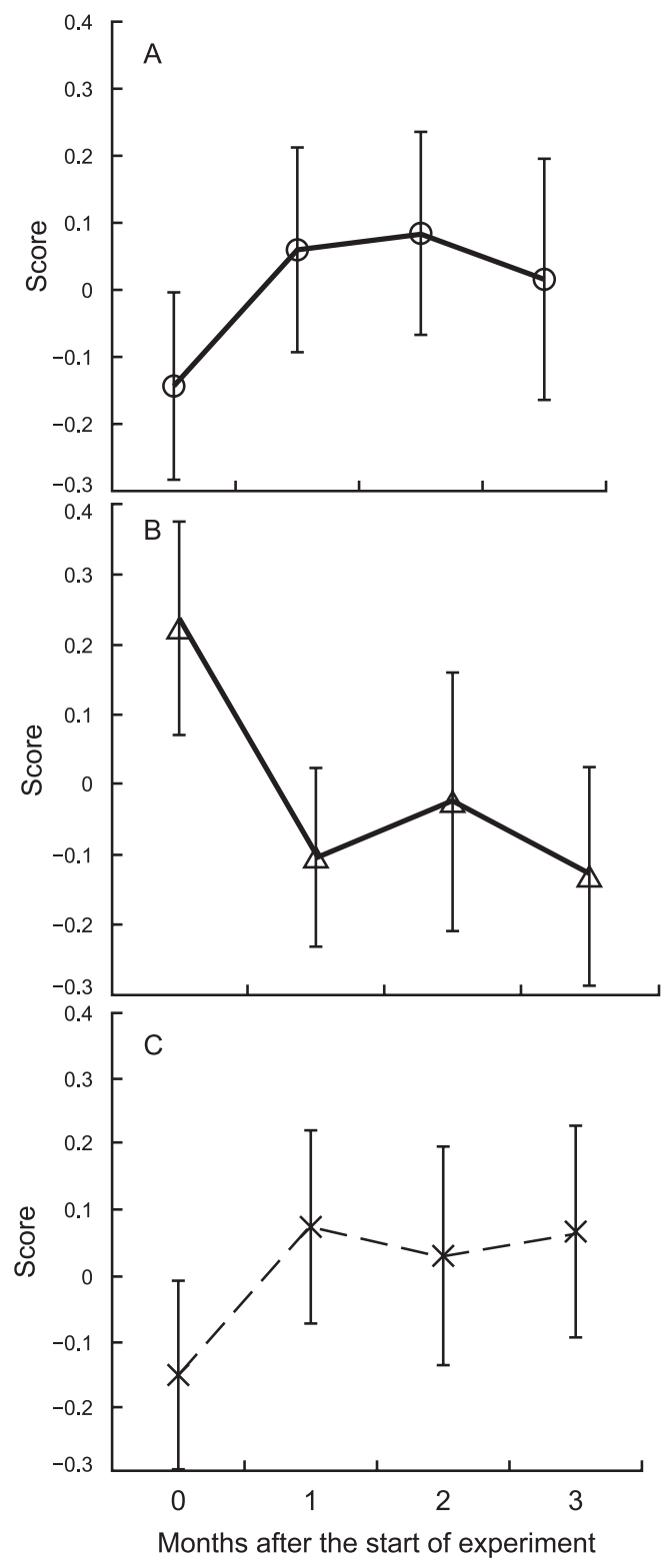

第 6 図 印象評価アンケートの主成分分析に拈ける因子スコ アの変化

A 因子 1: 快適性（寄与率 45\%)

B 因子 2: 簡素さ・清潔さ（寄与率 9.2\%)

C 因子 3: 華やかさ（寄与率 6.6\%)

縦棒は標準誤差を示す（n=38～46)

POMS の A-H が低下していることから今回の被験者の「怒 り」は引き起こされなかったと考えられる．花色の影響に ついてはさらに検討する必要がある.

一方で，鉢物やその培地が室内の揮発性有機化合物を除 去する（Wood ら，2002）ことは報告されているが, 「空気 がきれい」と関係する「シンプルさ」は低下する傾向が認 められた (第 6 図). 本研究で使用したシクラメンが花粉の 多い品種であることが視覚的に不快なイメージとして影響 したと考えられる.より花粉の少ない品種の方が室内の空 気がきれいなイメージを与えることが予測される.
松尾（1998）は趣味園芸や農業教育において，植物を育 てることの重要性を述べているが，本研究に拈いては，子 育て経験者の生育 Grade は3.5 であり，経験してない被験 者の 2.6 に比べて有意に高かった. これは，「育てる」とい ら点に打いて何らかの共通点があることを示唆している.

また，家の中に植物をいつも飾っている（5 ポイント）か らまったく無い(1ポイント) まで 5 段階に分けて問らた 結果, 植物を飾る程度と生育 Grade に有意な相関があった ことから，日頃の園芸に対する経験も生育に影響したもの と考えられた．これらのことから，福井（2006）が指摘す るように，栽培経験の少ない消費者にも満足してもららた めに，多様な管理に耐えらるような日持ちの良い品種の選 択や出荷前の管理方法の検討とともに, 分かりやすい栽培 情報の提供などが必要であろら。

以上のことからホームユース鉢物の生育状況と消費者 の心理や満足度とは相互に影響を及ぼしあらことが示唆 された。

\section{摘 要}

冬季に人気の高い室内植物であるシクラメン鉢物を用 い, 育てる人による生育の違いやその生育状況が人に与え る影響を調査した。栃木県在住の女性（46 名，平均 46.1 才）を被験者とし，各自宅で栽培してもらいながら生育と 心理的な調査を行った. 3 か月間の生育と品質は被験者に よる変動が大きかったため, 植物の生育状態別により被験 者を五つの Grade に分類した．植物の生育と被験者の自己 評価 $(r=0.7, p<0.001)$, 満足感 $(r=0.61, p<0.001)$ 扎よ び楽しさ $(r=0.38, p<0.012)$ との間には有意な相関が認め られた．気分を評価するPOMS の測定では植物の介入に よって緊張一不安, 抑らつ一落込及 (D), 怒り一敵意 (AH）扣よび混乱の得点の有意な低下が認められた．特に Grade 5（生育良好）の被験者に打いてD打よびA-H の顕 著な低下が認められた. Grade 5 グループにおいてエゴグラ ムの適応した子供の自我が低下し, 養育的, 大人の自我拉 よび自由な子供の自我の得点が増加傾向にあった。鉢物を 置いた部屋の印象を26 項目のSD法で解析したところ,「快 適さ」と「華やかさ」は高まり,「簡素さ・清潔さ」は低下 する傾向が認められた．以上の結果から，鉢物が消費者の

D， A-H，「快適さ」などの感情に好影響を与えるだけでな く，その生育状況と満足や楽しさなどに関係があることが 示唆された.

謝 辞 被験者の皆様とアンケート調査の設計について ご指導を頂いた宇都宮大学国際学部の中村 真准教授に厚 く感謝いたします。

\section{引用文献}

遠藤まどか・三島孔明・藤井英二郎．2001．プランターで の植物栽培が脳波, 心拍変動, 感情に及ぼす影響. 人 間・植物関係学会雑誌. 1:21-24. 
Fjeld, T. 2000. The effect of interior planting on health and discomfort among workers and school children. HortTechnology 10: 46-52.

深澤眞悟. 2005. ガーデニング教室参加者の気分変化. 人 間・植物関係学会誌. 5: 13-15.

福井博一. 2006. シクラメンのマーケティング. 農耕と園 芸. $61(2): 24-28$.

林 典夫 - 寺内桂子 - 三宅孝昭 - 清水教永 - 堀内昭作 - 黒 岡 浩. 1999. コミュニティガーデンの設置・運営に 関する基礎研究 第三報 コミュニティガーデン活動 の心理的評価について. 園学雑. 68 (別 2) : 460 .

今西弘子・生尾昌子・稲本勝彦・土井元章・今西英雄. 2002. 植物の存在がオフィスで働く人々に与える心理的効 果. 園学研. 1:71-74.

金 恩一・藤井英二郎. 1995. 植物の色彩の生理 - 心理的 効果に関する基礎的研究. ランドスケープ研究. 58: 141-144.

Lohr, V. I., C. H. Pearson-Mims and G. K. Goodwin. 1996. Interior plants may improve worker productivity and reduce stress in a windowless environment. J. Environ. Hort. 14: 97-100.

松尾英輔. 1998. 園芸療法を探る一癒しと人間らしさを求 めて一. グリーン情報. 名古屋.

日本色彩学会. 1998. 新編色彩科学ハンドブック (第 2 版). 東京大学出版会. 東京.

仁科弘重・中本有美. 1998. 観葉植物, 花, 香りが人間に 及ぼす生理心理的効果の脳波およびSD法による解析. 日本建築学会計画系論文集. 509: 71-75.
農林水産省. 2007 . 平成 18 年花き卸売市場調査結果の概要 統計表. p. 8 .

Parsons, R., L. G. Tassinary, R. S. Ulrich, M. R. Hebl and M. G. Alexander. 1998. The view from the road: Implications for stress recovery and immunization. J. Environ. Psychol. 18: 113-139.

Son, K. C. 2004. 気分を良くさせる室内植物, 精神健康に役 立つ緑色植物. p. 85-98. In: K. C. Son (ed.). 室内植物 が人を生かす（Horticultural Well-being). Joongang Life Publishing Co., ソウル (韓国語).

杉原式穂・青山 宏・竹田里江・池田 望・小林昭裕. 2005. 園芸療法が施設高齢者の精神機能および行動面に与え る効果. 老年精神医学雑誌. 16: 1163-1173.

東京大学医学部心療内科 TEG 研究会編. 1999. 新版 TEG 実施マニュアル。金子書房. 東京.

Wood, R. A., R. L. Orwell, J. Tarran, F. Torpy and M. Burchett. 2002. Potted-plant/growth media interactions and capacities for removal of volatiles from indoor air. J. Hort. Sci. Biotech. 77: 120-129.

山根健治・川島 桃・藤重宣昭. 2002. 鉢苗の移植作業が 脳波，筋電図，瞬き率，感情に及ぼす影響，人間・植 物関係学会雑誌. 2:34-38.

安川 緑・岩元 純・原 等子・松尾英輔・吉川敏一. 2000. 園芸療法による高齢者の心身機能の変化と Healing 効 果に関する研究. (財) 木村看護教育振興財団平成 11 年度看護研究助成事業看護研究集録. 8: 77-87.

横山和仁. 荒記俊一. 1994. 日本版 POMS 手引. 金子書房. 東京. 